Journal of Conflict \& Security Law (C) Oxford University Press 2012; all rights reserved. For permissions, please e-mail: journals.permissions@oup.com doi:10.1093/jcsl/krr019

\title{
International Law as a Regulatory Framework for Sexual Crimes Committed by Peacekeepers
}

\author{
Gabrielle Simm*
}

\begin{abstract}
International Law provides a framework for regulating sexual crimes committed by peacekeepers. This article includes in the definition of peacekeepers private military contractors and humanitarian non-government organization (NGO) workers, who increasingly act as subcontractors and partners in UN peace operations. Drawing on the socio-legal field of regulatory studies, this article assesses the ability of international law to function as a regulatory regime in terms of its ability to set standards, monitor compliance and enforce standards. It does this through a survey of the international law on jurisdiction, responsibility of states and international organizations, and immunity. The article argues that international law's strength lies in standard setting, but some of its standards are problematic, and it is weak in both monitoring and enforcement mechanisms due to its heavy reliance on states as regulators at international law.
\end{abstract}

\section{Introduction}

Over the past two decades, there has been a series of scandals implicating peacekeepers in the sexual exploitation and abuse of local people. Perhaps the best known are the cases of Cambodia ${ }^{1}$ and Somalia ${ }^{2}$ in the early 1990s, Liberia and Sierra Leone in $2002^{3}$ and the Democratic Republic of the Congo (DRC) in $2004 .^{4}$ The United Nations (UN) has responded to these events with investigations and policy changes, most notably the promulgation in 2003 of its

* Visiting Fellow, Regulatory Institutions Network (RegNet), Australian National University. E-mail: Gabrielle.Simm@anu.edu.au. Thanks to Hilary Charlesworth, Nigel White, Tina Dolgopol and an anonymous reviewer for very useful comments.

1 K Serey Phal, 'The Lessons of the UNTAC Experience and the Ongoing Responsibilities of the International Community for Peacebuilding and Development in Cambodia' (1995) 7 Pacifica Rev 129, 132; S Whitworth, Men, Militarism, and UN Peacekeeping: a Gendered Analysis (Lynne Rienner 2004) ch 3.

2 S Razack, Dark Threats and White Knights: The Somalia Affair, Peacekeeping, and the New Imperialism (University of Toronto Press 2004).

3 BBC, 'Child Refugee Sex Scandal' (26 February 2002) <http://news.bbc.co.uk/2/hi/ africa/1842512.stm> accessed 11 February 2009; A Naik, The West 'Africa Sex Scandal' (2003) <http://www.odihpn.org/report.asp?id=2561> accessed 22 June 2010.

4 K Holt, 'DR Congo's Shameful Sex Secret' (2004) BBC News $<$ http://news.bbc.co.uk/ go/pr/fr/-/2/hi/africa/3769469.stm> accessed 31 March 2009. 
zero tolerance policy on sexual exploitation and abuse..$^{5}$ The UN has also amended its model Memorandum of Understanding with troop-contributing countries to facilitate investigation and prosecution of military personnel ${ }^{6}$ and has proposed a new treaty to improve the criminal accountability of civilian UN personnel. ${ }^{7}$ Despite these efforts, reports of the sexual abuse of local people by peacekeepers continue. ${ }^{8}$

This article examines the role that international law plays in regulating sex between peacekeepers and local people. In addition to UN military, civilian and police personnel, this article also includes in the definition of peacekeepers private military contractors and humanitarian non-government organization (NGO) workers who increasingly act as subcontractors and partners in UN peace operations. ${ }^{9}$ Sex between peacekeepers and local people is not necessarily exploitative or abusive. ${ }^{10}$ However, this article focuses on sexual crimes committed by peacekeepers against local people. In the absence of a universally agreed criminal code, it will focus on rape and sexual assault as serious sexual offences reported to be committed by peacekeepers, recognising that the legal and evidentiary requirements for prosecution will vary with jurisdiction. ${ }^{11}$ Law is

5 'Sexual exploitation' is defined as 'any actual or attempted abuse of a position of vulnerability, differential power, or trust, for sexual purposes, including, but not limited to, profiting monetarily, socially or politically from the sexual exploitation of another'. Sexual abuse is defined as the 'actual or threatened physical intrusion of a sexual nature, whether by force or under unequal or coercive conditions'. SecretaryGeneral's Bulletin on special measures for protection from sexual exploitation and abuse (9 October 2003) UN Doc ST/SGB/2003/13 s 1; Prince Zeid, 'A comprehensive strategy to eliminate future sexual exploitation and abuse in United Nations peacekeeping operations' (9 February 2005) UN Doc A/59/710 (The Zeid Report).

6 Final text reproduced in Manual on Policies and Procedures concerning the Reimbursement and Control of Contingent-owned Equipment of Troop/Police Contributors participating in Peacekeeping Missions (29 January 2009) UN Doc A/C.5/63/18.

7 Report of the Group of Legal Experts, 'Ensuring the accountability of United Nations staff and experts on mission with respect to criminal acts committed in peacekeeping operations' Annex III Draft Convention on the criminal accountability of United Nations officials and experts on mission, UN Doc A/60/980 (16 August 2006).

8 BBC, 'Uruguayan Peacekeepers in Haiti Accused of Abuse' (5 September 2011) $<$ http://www.bbc.co.uk/news/world-latin-america-14783538> accessed 12 September 2011.

9 D Otto, 'Making Sense of Zero Tolerance Policies in Peacekeeping Sexual Economies' in V Munro and CF Stychin (eds), Feminist Engagements: Sexuality and the Law (Routledge 2007) 259, 267; EM Smith and TG Weiss, 'UN Task-sharing: Toward or Away from Global Governance?' in TG Weiss (ed), Beyond UN Subcontracting: Task-sharing with Regional Security Arrangements and Service-Providing NGOs (St Martin's Press 1998) 227, 227.

10 Otto (n 9); O Simić, 'Distinguishing between Exploitative and Non-Exploitative Peacekeeping Sex: The Wrongs of Zero Tolerance' (PhD Thesis, University of Melbourne 2011).

11 For example, the age of consent to sex varies between jurisdictions: in 2001 the age of marriage for girls was 14 in Sierra Leone, 16 in Liberia and not specified in Guinea: Otto (n 9) 271. 
a primary tool of regulation and one that could be expected to play an important role in preventing such crimes. One definition of a regulatory regime is that it sets standards, monitors compliance and provides a mechanism to enforce standards. ${ }^{12}$ This article looks at law through a regulatory lens by asking: How does law regulate sexual crimes committed by peacekeepers? This article does not attempt a survey of legal doctrine; rather, it responds to the following regulatory questions: What standards does law set? How does it monitor compliance? What enforcement mechanisms does law use?

There is a great deal of law, international and domestic, that is relevant to sexual crimes committed by peacekeepers. However, the coverage of law is uneven, with much international law applicable to individual peacekeepers in their capacity as members of state military forces and as representatives of an international organization. ${ }^{13}$ There is less international law applicable to private military contractors and almost no international law applying specifically to humanitarian NGO workers. This asymmetry is mirrored at the level of organizations, with much international law governing the responsibility of states and international organizations; fewer international obligations applying to Private Military and Security Companies (PMSCs); and almost no international law regulating NGOs. ${ }^{14}$

This article focuses primarily on the obligations of individuals and the responsibility of states and international organizations by examining three topics in international law that are key to regulating sexual crimes committed by peacekeepers. The topics are jurisdiction, responsibility of states and international organizations, and immunity. Jurisdiction is important because the laws governing exercise of jurisdiction are effectively forms of meta-regulation, in that they provide guidance on which state may regulate the activities in question.

12 C Parker et al. (eds), 'Introduction' in C Parker et al. (eds), Regulating Law (OUP 2004) 1.

13 This is an example of functional duality, where ' $[\mathrm{t}$ ]wo legal persons are in play on the commission of a single act': R Wilde, 'International Territorial Administration and Human Rights' in D Klaasen and ND White (eds), The UN, Human Rights, and Post-Conflict Situations (Manchester University Press 2005) 149, 170.

14 Although there have been a number of publications on NGOs in international law, they focus on the rights of NGOs to consult with international organizations and their role in making and monitoring compliance with international law, rather than on their obligations, which are 'underdeveloped' at international law: A-K Lindblom, Non-governmental Organisations in International Law (CUP 2005) 190. See further, MT Kamminga, 'The Evolving Status of NGOs under International Law: A Threat to the Inter-State System?' in P Alston (ed), Non-State Actors and Human Rights (OUP 2005) 93; Pierre-Marie Dupuy, 'Conclusion: Return on the Legal Status of NGOs and on the Methodological Problems which Arise for Legal Scholarship' in P-M Dupuy and L Vierucci (eds), NGOs in International Law: Efficiency in Flexibility? (Edward Elgar 2008) 204; S Charnovitz, 'Nongovernmental Organizations and International Law' (2006) 100 AJIL 348; cf EB Bluemel, 'Overcoming NGO Accountability Concerns in International Governance' (2005-06) 31 Brooklyn J Intl Law 139 which deals specifically with accountability. 
The responsibility of states and international organizations is relevant to regulating sexual crimes committed by peacekeepers because it invokes responsibility at a higher level than that of the individual. The purpose of holding international organizations and states responsible is to make them influence the behaviour of individuals and other entities within their control. The law of state and international responsibility also raises interesting questions of attribution; that is, when are the acts of an individual or other entity (such as a corporation or NGO) attributable to a state or international organization? Immunity is vital to understanding the regulation of sexual crimes committed by peacekeepers, as it appears to contradict the purpose of regulation by exempting individuals and entities from responsibility. This article explores what the other regulatory goals of immunity are and to what extent immunities should apply to sexual crimes committed by peacekeepers. Rather than attempting a comprehensive exposition of all the substantive law applying to sexual crimes committed by peacekeepers, the three legal topics provide an overview of the regulatory framework and the key issues that arise.

\section{International Law as a Regulatory Framework}

This article approaches international law from a regulatory perspective. The field of regulatory studies is interdisciplinary and draws on law, economics, politics, psychology, criminology, architecture and other social sciences to analyse influences on human behaviour. ${ }^{15}$ It offers a way of thinking about law that does not understand law as the primary or only solution to regulatory problems.

15 On regulatory studies influenced by law, see H Collins, Regulating Contracts (OUP 1999); K Sikkink, 'From State Responsibility to Individual Criminal Accountability: a New Regulatory Model for Core Human Rights Violations' in W Mattli and N Woods (eds), The Politics of Global Regulation (Princeton University Press 2009) 121; by economics: J Braithwaite, Markets in Vice, Markets in Virtue (Federation Press 2005); D Levi-Faur and J Jordana, 'The Rise of Regulatory Capitalism: The Global Diffusion of a New Order' (2005) 598 Ann Am Acad Polit Soc Sci 200; by politics: J Jordana and D Levi-Faur, 'The Politics of Regulation in the Age of Governance' in J Jordana and D Levi-Faur (eds), The Politics of Regulation: Institutions and Regulatory Reforms for the Age of Governance (Edward Elgar 2003) 1; PJ May, 'Regulatory Regimes and Accountability' (2007) 1 Regulation and Governance 8; by psychology: M Wenzel, 'Tax Compliance and the Psychology of Justice: Mapping the Field' in V Braithwaite (ed), Taxing Democracy: Understanding Tax Avoidance and Evasion (Ashgate 2003) 41; V Braithwaite, Defiance in Taxation and Governance: Resisting and Dismissing Authority in a Democracy (Edward Elgar 2009); by criminology and architecture: CD Shearing and PC Stenning, 'From the Panoptican to Disney World: The Development of Discipline' in Ron D Clarke (ed), Situational Crime Prevention: Successful Case Studies (Harrow and Heston 1997) 300; L Lessig, Code and other Laws of Cyberspace (Harrow and Heston 1999), updated by L Lessig, Codev.2 (2005) <http://codev2.cc/> accessed 15 November 2011. 
While law presents a range of options, including in the international context compensation, restitution, countermeasures, Security Council sanctions and the use of force, regulation is broader. Some branches of regulatory studies offer economic instruments, such as price signals, taxes, subsidies and markets, as regulatory mechanisms. ${ }^{16}$ Depending on the objective to be achieved, such instruments may prove more effective or suitable than traditional legal responses such as fines imposed as punishment or compensation in tort or contract. ${ }^{17}$ The sociological aspects of regulatory studies enable the social impact of regulation to be understood and used. So while criminal law might depend implicitly on stigma and shaming for part of its deterrent value, regulatory approaches explicitly consider communication and information sharing, which may include naming and shaming outside the criminal context, to be regulatory mechanisms in themselves, rather than a useful side effect of regulation. ${ }^{18}$

The relationship between regulation and law is contested and depends to a large extent on the definition of each. Julia Black outlines the options available for defining law, which range from a narrow definition of law as that which emanates solely from the state ${ }^{19}$ to the more expansive understanding of law used by legal pluralists, as 'concrete patterns of social ordering, the spontaneous rule-bound order of the "semi-autonomous social field", or the set of norms which actors abstract from practice and invest with binding authority. ${ }^{20}$ The definition of regulation is perhaps even more contested than the definition of law, and even the labels to be applied are open. For instance, Black suggests that 'governance', 'regulation' or 'control' are potentially equally applicable labels, each with its own drawbacks, but that what is more important is defining the concept to which the selected label should apply. ${ }^{21}$ Unlike law, the concept of regulation lays no claim to internal coherence or even legitimacy. ${ }^{22}$ Black settles on a 'decentred' definition of regulation that acknowledges the possibility of non-state regulators and sees the object of regulation as much wider than economic activity.

For many lawyers, regulation is 'less than law', 'simply a species of the genus "law". ${ }^{23}$ Lawyers see regulation as comprising those statutory instruments enacted with the explicit purpose of regulation but not extending to the dispute resolution, stabilising expectations or allocating authority tasks of the wider legal system. ${ }^{24}$ However, for some 'regulationists', regulation is not 'less than'

16 A Ogus, Regulation: Legal Form and Economic Theory (Hart 2004).

17 N Gunningham and P Grabosky, Smart Regulation: Designing Environmental Policy (Oxford: Clarendon Press, New York: Oxford UP 1998); N Gunningham, 'Environment Law, Regulation and Governance: Shifting Architectures' (2009) 21 J Environmental L 179.

18 J Braithwaite, Restorative Justice and Responsive Regulation (OUP 2002); J Braithwaite, Crime, Shame and Reintegration (CUP 1989) ch 5.

19 J Black, 'Critical Reflections on Regulation' (2002) 27 Australian J Legal Phil 1, 29.

20 ibid 30 (references omitted).

21 ibid 21.

22 ibid 32.

23 ibid 30.

24 ibid 31. 
law at all, rather the relationship is reversed: law is simply a technique or instrument that may or may not be involved in the practice of regulation. ${ }^{25}$ As Neil Gunningham puts it, referring to environmental law, today law is "no longer centre stage but simply one instrument among others in the environmental regulator's toolkit'. ${ }^{26} \mathrm{He}$ contrasts state-based law as 'that which is promulgated by parliament and interpreted by the courts' with regulation, which includes 'much more flexible, imaginative and innovative forms of social control which seek to harness not just governments but also markets (as with economic instruments), business and third parties'. ${ }^{27}$ While regulation may utilize NGOs and commercial interests, it 'still involves the state as a central player because even mechanisms that are not reliant on legislation for their authority are negotiated directly with the state and operate "in the shadow of the state", ${ }^{28}$ This approach of seeing law as something which can be regulated, or even seeing law as a subset of regulation, is both unsettling and productive for lawyers. ${ }^{29}$ While socio-legal scholars and regulationists are both concerned with 'law in action' rather than 'law in the books', ${ }^{30}$ regulation asks different questions: about effectiveness rather than coherence. ${ }^{31}$

This article uses criteria derived from regulatory studies to evaluate how international law regulates sexual crimes committed by peacekeepers. Applying Niklas Luhmann's sociological theory to law, Gunther Teubner sees law as a self-regulating, or autopoietic, system. ${ }^{32}$ Teubner's theory was developed in relation to the social welfare state and in this context he identifies a regulatory trilemma setting out the three risks of regulation. ${ }^{33}$ The first is that regulation risks being irrelevant, that is, ineffective because people fail to comply. Regulatory studies examine the extent of and reasons for compliance with regulation to assess its impact on daily life. Regulation fails if social norms are indifferent to legal intervention. ${ }^{34}$ Second, regulation risks being 'non-responsive to existing norms, values and social orderings,' where there is juridification of the social. ${ }^{35}$ Regulatory scholars ask: To what extent does law allow responsiveness to social facts and norms? To what extent are the values and techniques of regulation consonant with pre-existing social norms, or do they compete with them? However, there may be situations where law is

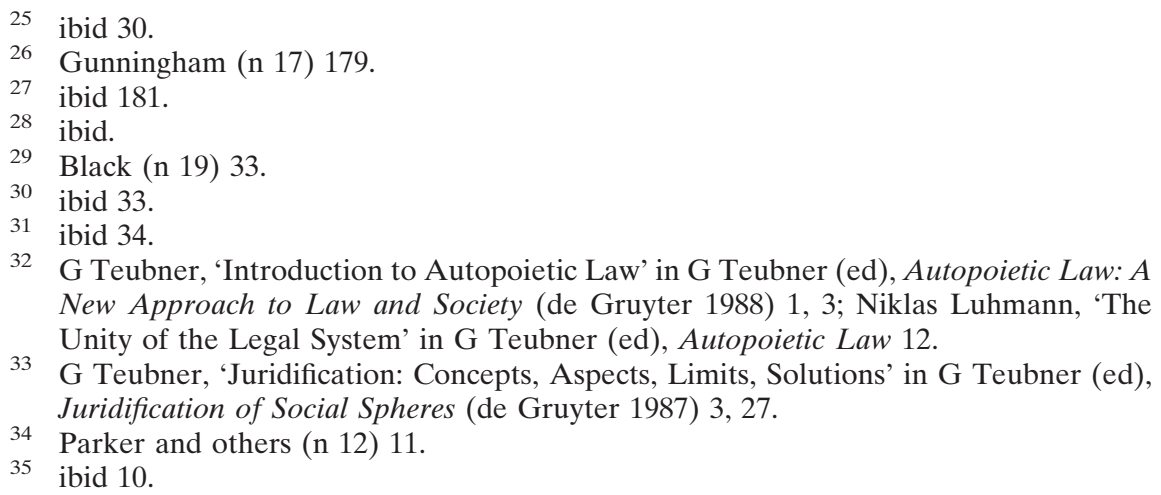


designed to alter social norms, such as those of impunity. Third, regulation risks being incoherent, where social norms overwhelm law. ${ }^{36}$ To what extent are legal doctrines and principles corrupted by the imperative of regulation to be effective and responsive? An example in the context of sexual crimes committed by peacekeepers might be a concern that the human right of an accused peacekeeper to a fair trial is jeopardized by the drive for accountability. The application of the regulatory trilemma to international law is a novel but productive way of analysing whether the international law examined falls prey to any of these risks of regulation.

\section{Jurisdiction}

At international law, the regulatory function of the meta-rules on jurisdiction is to provide guidance on when different states may exercise jurisdiction over behaviour. ${ }^{37}$ There are five potential bases of state jurisdiction: territorial, nationality, passive nationality, protective or security and universality. ${ }^{38}$ The territorial principle enables states to exercise jurisdiction over persons in their territory. ${ }^{39}$ In peacekeeping, territorial jurisdiction is exercised by a host state, such as the DRC, Bosnia, Liberia or Sierra Leone. All other types of jurisdiction are extraterritorial and are conceptualized as either prescriptive (seeking to influence future behaviour) or adjudicative/enforcement (seeking to enforce existing law). ${ }^{40}$ The nationality principle enables sending states, states whose nationals are employed as peacekeepers, to exercise jurisdiction over their own nationals, which may include legal persons such as corporations. ${ }^{41}$ For example,

36 ibid.

37 A Reinisch, 'The Changing International Legal Framework for Dealing with Non-State Actors' in P Alston (ed), Non-State Actors and Human Rights (OUP 2005) 37, 57.

38 Another basis for jurisdiction recognized in some European states is representation: L Reydams, Universal Jurisdiction: International and Municipal Legal Perspectives (OUP 2003) 22; C Ryngaert, Jurisdiction in International Law (OUP 2008) 88-102. Representational or vicarious jurisdiction, which applies where a state is acting on behalf of, or representing, another state that is more directly involved: I Cameron, 'Jurisdiction and admissibility issues under the International Criminal Court Statute' in D McGoldrick, P Rowe and E Donnelly (eds), The Permanent International Criminal Court (Hart 2004) 65, 77-78. Sometimes considered a separate head of jurisdiction, it might apply in a peacekeeping mission where Jordan requests extradition of a Jordanian peacekeeper held in France for crimes committed in Liberia, but France prosecutes her in France due to concerns about the right to a fair trial in Jordan. See further Ryngaert 102-04.

39 This schema includes flag state jurisdiction in territorial jurisdiction.

40 O De Schutter, 'The Responsibility of States' in S Chesterman and A Fisher (eds), Private Security, Public Order: The Outsourcing of Public Services and Its Limits (OUP 2009) 25, 34, 36-38.

41 On the nationality of corporations, see Barcelona Traction, Light and Power Co, Ltd (Belgium v Spain)(Merits) [1970] ICJ Rep 3 [70]. 
the nationality principle enables Pakistan to prosecute a Pakistani peacekeeper or the USA to prosecute a US private military contractor for acts committed while engaged in peacekeeping abroad. The passive personality principle allows states whose nationals are victims of a crime to exercise jurisdiction over that crime. ${ }^{42}$ It would enable Romania to exercise jurisdiction against a foreign national who had committed a crime against a Romanian national outside Romania, such as trafficking her to Bosnia. The protective or security principle applies when the security of the state is threatened and is not relevant to peacekeeping. ${ }^{43}$ Finally, the universality principle refers to acts that are universally condemned, such as breaches of jus cogens like piracy and torture or serious breaches of the Geneva Conventions, and therefore may be prosecuted by any state. ${ }^{44}$ For example, Belgium has asserted universal jurisdiction for crimes committed in the DRC that did not involve Belgian nationals as either perpetrators or victims. ${ }^{45}$

There is no general rule that specifies which basis of jurisdiction should take precedence and conflicts are solved according to technical rules without reference to the content of rules. ${ }^{46}$ The territorial and nationality principles are better accepted than the more controversial principles of passive nationality, protective and universality. ${ }^{47}$ An exception is the specification of which state may exercise jurisdiction contained in treaties, such as the UN model Status of Forces Agreement (SOFA), which provides that sending states exercise exclusive criminal jurisdiction (based on nationality) over their troops. ${ }^{48}$ In the absence of specification such as in a treaty, where more than one state wishes to assert jurisdiction, the principles are used as competing claims against each other. ${ }^{49}$ In the peacekeeping context, the most relevant principles of jurisdiction are those between the territorial (or host state) and the sending state (or state of nationality). As noted above, the passive personality principle is also potentially relevant. However, examples of states contesting jurisdiction over peacekeepers are rare, unsurprisingly given that there are very few prosecutions of peacekeepers at all.

\footnotetext{
Ryngaert (n 38) 92-93.

ibid 96-99.

A Cassese, International Criminal Law (OUP 2008) 338.

DRC v Belgium (Arrest Warrant) (Merits) [2002] ICJ Rep 3.

Reinisch (n 37) 58.

ibid 59.

48 Comprehensive Review of the Whole Question of Peace-Keeping Operations in all their aspects Model Status-of-forces agreement for peace-keeping operations (9 October 1990) UN Doc A/45/594 Annex, (Model SOFA) art 47(b).

49 G Simpson, 'On the Magic Mountain: Teaching Public International Law' (1999) 10 EJIL 70, 81.
} 
Given the evidence of complaints against peacekeepers broadly defined, and the acknowledgment from the $\mathrm{UN}^{50}$ and $\mathrm{NGOs}^{51}$ that underreporting is a major problem, why are states so reluctant to exercise jurisdiction? Host states may fail to exercise territorial jurisdiction due to the lack of a functioning legal system available to prosecute those accused of crimes. ${ }^{52}$ There may not be a court available to consider the question of whether the immunity of a peacekeeper applies. ${ }^{53}$ A host government may feel too intimidated to exercise jurisdiction over foreign nationals, particularly those of powerful states, or may feel unable to prosecute international staff of agencies and organizations providing assistance. ${ }^{54}$ Host state authorities may believe that exercise of jurisdiction is not possible due to immunities from which peacekeepers benefit. ${ }^{55}$ Private military contractors are bound by the local law of the host state unless they are granted immunity from it. ${ }^{56}$ However, as with prosecutions of individual peacekeepers, there are practical reasons why private military contractors are unlikely to be prosecuted in host states. ${ }^{57}$ These include the reluctance of host states to prosecute for political reasons as well as the factual dependence of some host states on PMSCs for their security. ${ }^{58}$

Sending states have likewise proven reluctant to prosecute their nationals for a range of reasons. Their domestic law may not permit the exercise of extraterritorial jurisdiction. ${ }^{59}$ It may be difficult and expensive to meet evidentiary

$50-$, 'Report of the Office of International Oversight Services on its investigation into allegations of sexual exploitation and abuse in the Ituri region (Bunia) in the United Nations Organization Mission in the Democratic Republic of the Congo' (5 April 2007) UN Doc A/61/841 [13].

51 K Lattu and HAP (Humanitarian Accountability Partnership), 'To Complain or Not to Complain: Still the Question' (Report, 2008) <http://www.hapinternational.org/pool/files/bbc-report-lowres.pdf> accessed 3 December 2011.

52 B Oswald and S Finnin, 'Combating the Trafficking of Persons on Peace Operations' in $\mathrm{H}$ Langholtz, B Kondoch and A Wells (eds), International Peacekeeping: The Yearbook of International Peace Operations, vol 10 (Martinus Nijoff 2006) 1, 23.

53 M Zwanenberg, 'UN Peace Operations between Independence and Accountability' (2008) 5 Intl Organizations L Rev 23, 39.

54 FJ Hampson and A Kihari-Hunt, 'The Accountability of Personnel Associated with Peacekeeping Operations' in C Aoi, E De Coning and R Thakur (eds), Unintended Consequences of Peacekeeping Operations (United Nations University Press 2007) 195, 207.

55 R Capps, 'Sex-Slave Whistle-Blowers Vindicated' (2002) <http://dir.salon.com/story/ news/feature/2002/08/06/dyncorp/print.html> accessed 14 September 2008.

56 For example, the Dayton Accords granted immunity to the International Police Task Force, the US component of which were largely private military contractors: General Framework Agreement for Peace in Bosnia and Herzegovina 35 ILM 751996 (signed and entered into force 14 December 1995) Annex 11, art 6.

57 M Frulli, 'Immunity for Private Military Contractors: Legal Hurdles or Political Snags' in F Francioni and N Ronzitti (eds), War By Contract: Human Rights, Humanitarian Law and Private Contractors (OUP 2011) 448, 455-59.

58 C Lehnardt, 'Individual Liability of Private Military Personnel under International Criminal Law' (2008) 19 EJIL 1015, 1031.

59 Hampson and Kihari-Hunt (n 54) 195, 203. 
requirements for a criminal prosecution when the victim and witnesses are in another jurisdiction. Sending states have been reluctant for political reasons to prosecute members of their national defence forces for crimes committed while on duty as UN peacekeepers. For example, in 2005 the UN Office of Internal Oversight Services (OIOS) reported that two of the three contingents whose members where being investigated for sexual exploitation and abuse in the DRC actively interfered with the investigations. ${ }^{60}$ Subjecting peacekeepers to local courts could make recruitment of personnel much more difficult. ${ }^{61}$ This is a practical problem, not just for the UN in recruiting peacekeepers, but also for sending states that rely on the income generated from payments for troop contributions to peace operations. Prosecuting sexual crimes against women in military courts may also prove problematic due to the particular masculinized culture of the military. ${ }^{62}$ Reluctance on the part of sending states to prosecute national contingent members is a serious problem as jurisdiction on the basis of nationality may be the only jurisdiction that exists, due to the immunity of national contingent members from host state jurisdiction under the SOFA. ${ }^{63}$

Private military contractors may also have obligations under sending state law; ${ }^{64}$ however, there are no examples of prosecution of private military contractors by sending states in UN peacekeeping missions. ${ }^{65}$ The US exercises extensive extraterritorial jurisdiction in comparison with many other states; yet even the USA lacks the jurisdiction to prosecute abuses committed by its nationals employed as private military contractors abroad in a number of situations. ${ }^{66}$ In addition to these legal and evidentiary problems, there remain practical and political barriers. The lack of monitoring and the attendant shielding from accountability may benefit governments that use PMSCs for activities with which they do not want to be associated, while the lack of scrutiny may suit PMSCs. ${ }^{67}$ Another practical difficulty in regulating private military contractors

-, 'Investigation by the Office of Internal Oversight Services into allegations of sexual exploitation and abuse in the United Nations Organization Mission in the Democratic Republic of the Congo' (Report, 5 January 2005) UN Doc A/59/661 [38].

61 F Rawski, 'To Waive or Not to Waive: Immunity and Accountability in UN Peacekeeping Operations' (2002) 18 Connecticut J Intl Law 103, 129.

62 B Bedont, 'The Renewed Popularity of the Rule of Law: Implications for Women, Impunity, and Peacekeeping' in D Mazurana, A Raven-Roberts and J Parpart (eds), Gender, Conflict and Peacekeeping (Rowman and Littleford 2005) 83, 90.

63 Model SOFA art 47(b).

64 Lehnardt (n 58) 1031-32.

65 The US Military Extraterritorial Jurisdiction Act (MEJA) may apply to US military engagements abroad in limited circumstances: C Ryngaert, 'Litigating Abuses Committed by Private Military Companies' (2008) 19 EJIL 1035, 1043-44.

66 The Civilian Extraterritorial Jurisdiction Act has been proposed to cover some of these gaps: D Isenberg, 'Contractors and the Civilian Extraterritorial Jurisdiction Act' <http://www.huffingtonpost.com/davidisenberg/contractors-and-the civil-b-446298.html> accessed 5 December 2011.

67 J Cockayne, 'Make or Buy? Principal-Agent Theory and the Regulation of Private Military Companies' in S Chesterman and C Lehnardt (eds), From Mercenaries to Market: The Rise and Regulation of Private Military Companies (OUP 2007) 196, 206. 
is the sending state's reliance on them to provide security, including the personal protection of investigators sent to investigate them. ${ }^{68}$ Given that it may be easier to meet a civil burden of proof than a criminal one, litigating civil claims such as in tort and contract is another way in which peacekeepers in general and private military contractors in particular may be regulated under sending state law. ${ }^{69}$ In such cases, the corporate structure of PMSCs potentially provides a shield from accountability. ${ }^{70}$

In the absence of prosecution of peacekeepers by host states or sending states, there are questions about alternative jurisdiction based on universal jurisdiction or the jurisdiction of an international criminal court or tribunal. It has been argued that sexual crimes committed by UN peacekeepers could be prosecuted on the basis of universal jurisdiction in a third-party state, provided that appropriate legislation exists. ${ }^{71}$ However, there is no known example of a third state claiming jurisdiction for a crime committed by a peacekeeper. ${ }^{72}$ The majority of 'crimes committed by peacekeeping personnel do not rise to levels allowing for universal jurisdiction ${ }^{73}$ Moreover, it is doubtful whether the UN peacekeeping setting could constitute an 'armed conflict' for the purposes of prosecuting rape as a war crime, even under the Statute of the International Criminal Tribunal for the former Yugoslavia (ICTY). ${ }^{74}$ The requirements for prosecuting sexual crimes as crimes against humanity or genocide are also very stringent and unlikely to be met in the case of peacekeepers. ${ }^{75}$

The International Criminal Court (ICC) has been suggested as a likely forum for prosecuting crimes committed by peacekeepers. ${ }^{76}$ This may be because the Rome Statute, which establishes the ICC, is generally regarded as progressive in

68 Lehnardt (n 58) 1032.

69 ibid 1034; Zwanenberg (n 53) 40.

70 For example, the US PMSCs Titan and CACI, which supplied interpreters and interrogators to the US government, were sued under the Alien Tort Claims Act for abuses committed in Abu Ghraib prison, Iraq. However, the plaintiffs faced difficulty in establishing liability of the US parent company for acts attributed to its Iraqi subsidiary: Saleh et al v Titan Corp 353 F Supp 2d 1087 (DDC 2004); Ibrahim et al v Titan Corp, 391 F Supp 2d 10 (DDC 2005) cited at fn 10 in Ryngaert (n 65) 1050, 1039.

71 M Ndulo, 'The United Nations Responses to the Sexual Abuse and Exploitation of Women and Girls by Peacekeepers during Peacekeeping Missions' (2009) 27 Berkeley J Intl Law 127, 156.

72 Hampson and Kihari-Hunt (n 54) 204.

73 CE Sweetser, 'Providing Effective Remedies to Victims of Abuse by Peacekeeping Personnel' (2008) 83 NYU L Rev 1643, 1657.

74 Statute of the International Tribunal for the former Yugoslavia, adopted by SCR 827 (23 May 1993) UN Doc S/RES/827 art 5.

75 Rome Statute of the International Criminal Court (adopted 17 July 1998, entered into force 1 July 2002) 2187 UNTS 90 (Rome Statute) arts 6(b) and 7(1)(g).

76 M O'Brien, 'Sexual Exploitation and Beyond: Using the Rome Statute of the International Criminal Court to Prosecute UN Peacekeepers for Gender-based Crimes' (2011) 11 Intl Crim L Rev 803. 
its approach to gender crimes. ${ }^{77}$ Another reason for looking to the ICC may be its complementary jurisdiction to prosecute where states are unwilling or unable to exercise national jurisdiction, for the reasons outlined above. ${ }^{78}$ If available, the ICC would be a very useful mechanism to ensure accountability and thereby increase the relevance of international law to sexual crimes committed by peacekeepers. However, the ICC may only exercise jurisdiction over crimes committed after its entry into force and its competence is limited to strictly defined crimes. ${ }^{79}$ Most crimes committed by peacekeepers will be 'ordinary' as opposed to international crimes and will fall outside the ICC's jurisdiction. ${ }^{80}$ Further, the USA has concluded a large number of bilateral agreements under Article 98(2) of the Rome Statute in an attempt to prevent its nationals being subject to ICC jurisdiction. ${ }^{81}$ In addition, the ICC prosecutor's policy of targeting the most serious crimes and leaving the task of prosecuting lower level crime to domestic courts means it is unlikely that peacekeepers would be prosecuted at the ICC. $^{82}$

Apart from the exercise of extraterritorial jurisdiction, states have other means of regulating their nationals, including corporations. Olivier De Schutter refers to the possibility of

inserting clauses in public procurement schemes referring to human rights obligations, imposing reporting and other obligations on publicly listed or government-certified companies, and including conditions in project financing agreements with export credit agencies. ${ }^{83}$

Decentralized regulatory structures, such as the exercise of domestic jurisdiction by a range of states, may be less open to regulatory capture than a centralized structure, such as an international criminal tribunal. Regulatory capture occurs when the regulators fail to act in the public interest and act in the interests of those they regulate instead. ${ }^{84}$ A potential drawback of a decentralized structure is that 'the quality of the enforcement varies with the quality of

N Quénivet, 'The Role of the International Criminal Court in the Prosecution of Peacekeepers for Sexual Offenses' in R Arnold (ed), Law Enforcement within the Framework of Peace Support Operations (Martinus Nijhoff 2008) 399, 420.

78 Rome Statute, art 1.

79 ibid arts 11 and 5.

80 Bedont (n 62) 95.

81 DF Orentlicher, 'Unilateral Multilateralism: United States Policy Toward the International Criminal Court' (2003-04) 36 Cornell Intl L J 415, 425. See also UNSC Res 1422 (2002); UNSC Res 1487 (2003).

82 Rome Statute art 1; International Criminal Court, 'Paper on some policy issues before the Office of the Prosecutor' <http://www.icc-cpi.int/NR/rdonlyres/1FA7C4C6-DE5F42B7-8B25-60AA962ED8B6/143594/030905_Policy_Paper.pdf $>$ (2003) accessed 15 November 2011, 3.

83 De Schutter (n 40) 36.

84 G Stigler, 'The Theory of Economic Regulation' (1971) 2 Bell J Economics 3. 
criminal justice systems in different countries, ${ }^{85}$ NGOs that network with like-minded states play an important role in monitoring and publicising the enforcement of human rights regulation. ${ }^{86}$

Evaluating the international law of jurisdiction against the definition of a responsive regulatory regime shows that law is weak in a number of areas. First, the standard-setting function of the rules on jurisdiction is a set of guiding principles, rather than one of absolute rules, and conflicts are decided relative to which principles are contested in the circumstances of the case, instead of in the abstract. Secondly, the main way in which compliance is monitored is by states contesting jurisdiction in matters where they have an interest. In matters that affect primarily the interests of individuals or non-state entities and in which other states have no interest, relying on states to monitor compliance is precarious. For example, when a national of one country is a victim of a crime committed by a peacekeeper who is a national of another country, the victim's state may not be willing or able to assert jurisdiction on the basis of passive personality in the event that neither the host state nor sending state exercises jurisdiction. Thirdly, enforcement of standards relies on state regulation, which is subject to the same problems of monitoring compliance. Nevertheless, there are some promising options for overcoming these problems. These include a NATO precedent that envisages potential concurrent jurisdiction and provides rules to resolve conflicts. ${ }^{87}$ This is preferable to the exclusive jurisdiction of the sending state provided for in the UN model SOFA without the backup of host state jurisdiction. A group of legal experts proposed to amend the UN model MOU to require sending states of peacekeepers accused of sexual exploitation and abuse to report to the UN every 120 days on the progress of investigations and disciplinary or prosecution actions; however, states did not adopt this obligation in the final version of the model MOU approved by the General Assembly. ${ }^{88}$

The regulatory risks here are, on the part of host states, the perceived impact of immunity, and on the part of sending states, inadequate legal frameworks. In terms of Teubner's regulatory trilemma, these problems with jurisdiction are best analysed in terms of the risk that the law is irrelevant. Depending on the sending state, the risk of prosecution of a peacekeeper for sexual crimes is so remote as to be irrelevant. The problem of exercising extraterritorial jurisdiction

85 K Sikkink, 'From State Responsibility to Individual Criminal Accountability: a New Regulatory Model for Core Human Rights Violations' in W Mattli and N Woods (eds), The Politics of Global Regulation (Princeton University Press 2009) 121, 129.

Agreement between the parties to the North Atlantic Treaty regarding the Status of their Forces (signed 19 June 1951, entered into force 23 August 1953) 199 UNTS 67 art VII (3).

88 Revised draft model memorandum of understanding between the United Nations and [participating State] contributing resources to [the United Nations Peacekeeping Operation], UN Doc A/61/494 (3 October 2006) art 7 septiens (1); cf Comprehensive review of a strategy to eliminate future sexual exploitation and abuse in United Nations peacekeeping operations, GA Res 61/267, UN Doc A/RES/61/267B (24 July 2007) [2]; final text reproduced in the Model MOU. 
may be more or less easily remedied, depending on the constitutional and legal framework of particular states. The next section considers the responsibility of states and international organizations at international law.

\section{Responsibility of States and International Organizations}

The regulatory purpose of the law of international responsibility is to hold states and international organizations ${ }^{89}$ liable for breaches of international law in appropriate circumstances and to provide remedies for loss caused. This is an area of international law in which the dominance of states as both regulators and regulatees is particularly prominent, ${ }^{90}$ with the rules on the responsibility of international organizations developed to some extent by analogy with the rules on state responsibility. ${ }^{91}$ The International Law Commission (ILC) aims to progressively develop and codify international law. ${ }^{92}$ Its Articles on State Responsibility, developed over more than 40 years, were not presented as a draft Convention for adoption by states, but rather were adopted by the UN General Assembly and commended to states and international courts and tribunals. ${ }^{93}$ The law of state responsibility is important, given the marginal status of non-state actors at international law. ${ }^{94}$ Individuals, companies and NGOs figure only as potential agents of a state or international organization, and their conduct is significant only when it is attributable to an entity with international legal personality. ${ }^{95}$ As a result, the discussion here focuses on the concept of attribution.

89 An international organization is defined as 'an organization established by a treaty or other instrument governed by international law and possessing its own international legal personality. International organizations may include as members, in addition to States, other entities.' ILC 2009 art 2.

90 International Law Commission, Responsibility of States for Internationally Wrongful Acts, GA Res 56/83, UN Doc A/RES/56/83 (2001), Annex (ILC 2001) arts 42 and 48.

91 'When in the study of the responsibility of international organizations the conclusion is reached that an identical or similar solution to the one expressed in the articles on State responsibility should apply with respect to international organizations, this is based on appropriate reasons and not on a general presumption that the same principles apply.' International Law Commission, 'Report of the Sixty-third session' (26 April-3 June and 4 July-12 August 2011) (UN Doc A/66/10). Ch V Responsibility of international organizations, General Commentary [4] (ILC 2011).

92 Establishment of an International Law Commission, GA Res 174(II) (21 November 1947), UN Doc A/RES/174 (II) adopted pursuant to the UN Charter art 13.1.

93 J Crawford, The International Law Commission's Articles on State Responsibility: Introduction, Text and Commentaries (CUP 2002) 59.

94 Reinisch (n 37); J Klabbers, '(I Can’t Get No) Recognition: Subjects Doctrine and the Emergence of Non-State Actors' in A Bianchi (ed), Non-State Actors and International Law (Ashgate 2009) 37.

95 For example, '[t]he study should not encompass questions of responsibility of non-governmental organizations, because they do not generally exercise governmental functions and moreover would not raise the key question of the responsibility of member States for the conduct of the organization.' Giorgio Gaja, First report of the Special Rapporteur on responsibility of international organizations, UN Doc A/CN.4/ 532 (2003) [21]. 
The law of state responsibility requires a breach of international law attributable to a state. ${ }^{96}$

The policy rationale underlying such 'vicarious' or 'subsidiary' liability is clear: to increase pressure on states by continuing to hold them responsible for 'out-sourced' or 'delegated' activity in order to make sure that they have a direct interest in regulating the behaviour of non-state actors to whom they have transferred state tasks. ${ }^{97}$

There are a number of ways in which attribution may occur and, as this is the most contested and relevant aspect of state responsibility to sexual crimes committed by peacekeepers, attribution will be discussed in more detail below. A state may also be in breach of its obligation to exercise due diligence to prevent breaches of international law. ${ }^{98}$ This is most clearly established in international human rights law, where the state is responsible for failure to prevent rape and failure to provide a remedy for rape as a form of torture. ${ }^{99}$ For example, states parties to the International Covenant on Civil and Political Rights are obliged to ensure the human rights of anyone within their effective control or power, which extends outside their territory, including those in the control of their peacekeeping forces. ${ }^{100}$ The duty of due diligence also applies to international humanitarian law (IHL) ${ }^{101}$ and may impose obligations on both the host state or a sending state. ${ }^{102}$ In the case of private military contractors, this may require national soldiers 'to call to order to try to stop contractors in their vicinity who are about to commit or already committing a violation of IHL'. ${ }^{103}$ The law of state responsibility provides for circumstances precluding wrongfulness, which relieve a

${ }^{96}$ ILC 2001 Annex arts 1 and 2.

97 Reinisch (n 37) 81.

98 Corfu Channel (UK v Albania) (Merits) [1948] ICJ Rep 4, 23.

${ }_{99}$ Peru was held responsible for failing to provide an effective remedy for the rape of a woman by Peruvian security forces: Raquel Martin de Mejia v Peru Report No 5/96, Case 10970, Annual Report of the InterAmerican Commission on Human Rights 1995 OEA/Ser.L/V/II.91 Doc7 rev, 28 February 1996.

100 UN Human Rights Committee 'General Comment 31' (on art 2 of the Covenant: the Nature of the General Legal Obligation imposed on States Parties to the Covenant) (21 April 2004) UN Doc CCPR/C/74/CRP.4/Rev.6 [10]; Al-Skeini v UK App No 55721/07 7 July 2011; C Bakker, 'Duties to Prevent, Investigate and Redress Human Rights Violations by Private Military and Security Companies: The Role of the Host State' in F Francioni and N Ronzitti, War by Contract: Human Rights, Humanitarian Law and Private Contractors (OUP 2011) 130, 133-34.

101 Case concerning Armed Activities on the Territory of the Congo (Democratic Republic of the Congo v Uganda) (Merits) [2005] ICJ Rep 116 [178]; A Faite, 'Involvement of Private Contractors in Armed Conflict: Implications under International Humanitarian Law' (2004) 4 Defence Studies 166, 176.

102 De Schutter (n 40) 33-34.

103 C Hoppe, 'Passing the Buck: State Responsibility for Private Military Companies' (2008) 19 EJIL 989, 993. 
state of responsibility. ${ }^{104}$ Once state responsibility for an internationally wrongful act is established, a number of remedies are available. These include cessation and non-repetition, ${ }^{105}$ reparations such as restitution which aims to restore the situation to that which existed prior to the injury, ${ }^{106}$ compensation to the extent that restitution is not possible, ${ }^{107}$ and satisfaction, which includes apology and acknowledgment of breach. ${ }^{108}$

The three modes of attribution most relevant to sexual crimes committed by peacekeepers are via the conduct of a state organ, conduct of an entity empowered to exercise governmental authority and conduct under the direction or control of the state. First, conduct of a de jure organ of the state, such as its military forces, is attributable to the state. ${ }^{109}$ Secondly, conduct of entities empowered to exercise governmental authority, or de facto organs of the state, is also attributable to the state. ${ }^{110}$ This is most relevant to PMSCs or NGOs where they are empowered to exercise elements of governmental authority, such as in the case of PMSCs hired by a state. ${ }^{111}$ Thirdly, conduct directed or controlled by a state is attributable to the state. ${ }^{112}$ While this rule was developed by the International Court of Justice (ICJ) in a series of cases involving the relationship between paramilitary forces and a state, it is also relevant to peacekeeping forces. ${ }^{113}$

An important issue in attributing conduct, such as sexual crimes committed by peacekeepers, to a state is whether the conduct is official or off-duty. Acts of both de jure and de facto organs of the state are attributable to the state, even if they exceed authority or contravene instructions. ${ }^{114}$ It may be more difficult to attribute to the state the off-duty conduct of an employee of a PMSC than the off-duty conduct of national military forces. ${ }^{115}$ The ILC commentary on this

104 ILC 2001 arts 20-27.

105 ibid art 31.

106 ibid art 35.

107 ibid art 36.

108 ibid art 37.

109 ibid art 4.

110 ibid art 5.

111 L Doswald-Beck, 'Private Military Companies under International Humanitarian Law' in C Lehnardt and S Chesterman (eds), From Mercenaries to Market: The Rise and Regulation of Private Military Companies (OUP 2007) 115, 138.

112 ILC 2001 art 8.

113 Military and Paramilitary Activities in and against Nicaragua (Nicaragua $v$ United States) (Merits) (1986) ICJ Rep 14 [109]-[115]; Application of the Convention on the Prevention and Punishment of the Crime of Genocide (Bosnia and Herzegovina $v$ Serbia and Montenegro) (2007) ICJ Rep; ILC 2001 cf Prosecutor v Tadić (Appeal) ICTY-94-1-A (15 July 1999) [137]; see discussion of Behrami below.

114 ILC 2001 art 7. The International Court of Justice held that it was irrelevant that members of Ugandan military forces acted contrary to their instructions or exceeded their authority as it was well established at customary international law that the state is responsible for all acts of its armed forces: Case concerning Armed Activities on the Territory of the Congo (Democratic Republic of the Congo v Uganda) [2005] ICJ Rep 116 [214].

115 Hoppe (n 103) 990-91. 
Article makes clear that, provided the state organ is acting in its official capacity, ultra vires conduct is attributable to the state. ${ }^{116}$ It distinguishes cases "where officials acted in their capacity as such, albeit unlawfully or contrary to instructions' where conduct is attributable, from those where 'the conduct is so removed from the scope of their official functions that it should be assimilated to that of private individuals, not attributable to the State'. ${ }^{117}$ It continues:

The problem of drawing the line between unauthorized but still 'official' conduct, on the one hand, and 'private' conduct on the other, may be avoided if the conduct complained of is systematic or recurrent, such that the State knew or ought to have known of it and should have taken steps to prevent it. However, the distinction between the two situations still needs to be made in some cases, for example when considering isolated instances of outrageous conduct on the part of persons who are officials. ${ }^{118}$

This is particularly relevant to a discussion of 'outrageous' sexual crimes committed by peacekeepers, where media and UN reporting suggests that, while the conduct is not 'systematic,' with the possible exception of organized trafficking as in Bosnia, ${ }^{119}$ it is 'recurrent', such that states are or ought to be aware of it and take steps to prevent it.

The law of responsibility of international organizations shares many features with the law of state responsibility. The ILC began work on Articles on Responsibility of International Organizations in 2002. In 2009, it provisionally adopted draft articles on first reading and in 2011 it adopted the articles on second reading, taking into account the comments received from states and international organizations. ${ }^{120}$ The $\mathrm{UN}$ is an international organization with international legal personality separate from those of its members. ${ }^{121}$ Where an action or omission amounts to a breach of international law and that act is attributable to an international organization, the international organization is responsible for it. ${ }^{122}$ The law on attribution of conduct to international organizations varies from that of attribution to states and will be discussed separately.

116 ILC 2001 commentary to art 7 [1].

117 ibid commentary to art 7 [7].

118 ibid commentary to art 7 [8].

119 Bolkovac v DynCorp AeroSpace Operations (UK) Ltd (2002) Employment Tribunals Case No 3101729/01 [26]; 'The U.N. and the Sex Slave Trade in Bosnia: isolated case or larger problem in the U.N. system?' Hearing before the Subcommittee on International Operations and Human Rights of the Committee on International Relations, House of Representatives, US Congress (2002) <http://commdocs.house .gov/committees/intlrel/hfa78948.000/hfa78948_0f.htm> accessed 15 November 2011.

120 ILC 2011.

121 Reparation for injuries suffered in the service of the United Nations (Advisory Opinion) [1949] ICJ Rep 174, 179.

122 ILC 2011 art 4. For example, the UN's failure to prevent genocide in Rwanda constitutes a breach of an international obligation: G Gaja, 'Third Report of the Special 
Another less settled aspect of the law on the responsibility of international organizations is the extent to which they are bound by international law, with the UN bound by jus cogens, customary IHL and customary international human rights law. ${ }^{123}$ None of the circumstances precluding wrongfulness is relevant to sexual crimes committed by peacekeepers, with the possible exception of consent by a host state to the presence of the UN on a state's territory. ${ }^{124}$ However, consent to the presence of UN personnel on its territory does not imply consent to the commission of crimes or other acts outside the limits of its consent. ${ }^{125}$ If found responsible for an internationally wrongful act, international organizations have an obligation to cease the breach, perform the obligation, guarantee non-repetition of the breach, and make full reparation for the injury caused. ${ }^{126}$ As with state responsibility, reparations can take the form of restitution, compensation and satisfaction. ${ }^{127}$ Another option, which the UN cannot provide itself, is punishment according to criminal or administrative law by the relevant state of civil servants or military forces who actually committed the wrongful act. ${ }^{128}$

Attribution of conduct to the UN can occur in a number of ways. The two most relevant to peacekeeping operations are first, through the conduct of its organ or agent under Article 6 of the Articles on Responsibility of International Organizations, and secondly, through the conduct of organs or agents placed at its disposal by a state or another international organization under Article 7. 'Agent' means 'an official or other person or entity, other than an organ, who is charged by the organization with carrying out, or helping to carry out, one of

Rapporteur on responsibility of international organizations' UN Doc A/CN.4/553 (13 May 2005) [10].

123 A Clapham, Human Rights Obligations of Non-State Actors (OUP 2006) 65-67; ND White and D Klaasen, 'An Emerging Legal Regime?' in ND White and D Klaasen (eds), The UN, Human Rights and Post-conflict Situations (Manchester University Press 2005) 1; A Devereux, 'Selective Universality? Human-rights Accountability of the UN in Post-conflict Operations' in B Bowden, H Charlesworth and J Farrall (eds), The Role of International Law in Rebuilding Societies after Conflict: Great Expectations (CUP 2009) 198.

124 G Gaja, 'Fourth report on responsibility of international organizations' UN Doc A/ CN.4/564 (28 February 2006) [11]. Zwanenberg argues that the UN's rejection of claims arising from the ordinary operation of peacekeeping forces on the basis of 'operational necessity' does not fall within the ILC's definition of necessity as a circumstance precluding wrongfulness: Zwanenberg (n 53) 32.

125 'Valid consent by a State or an international organization to the commission of a given act by another international organization precludes the wrongfulness of that act in relation to that State or the former organization to the extent that the act remains within the limits of that consent.' ILC 2004 art 19.

126 ibid arts 28, 29 and 33.

127 ibid arts 34-36.

128 J Saura, 'Lawful Peacekeeping: Applicability of International Humanitarian Law to United Nations Peacekeeping Operations' (2007) 58 Hastings LJ 479, 524. 
its functions, and thus through whom the organization acts'; ${ }^{\prime 29}$ hence, this would be most relevant to civilian personnel. Peacekeeping forces are subsidiary organs of the UN and as such their conduct could be analysed as attributable to the UN under Article 6. However, since states retain control over disciplinary and criminal matters, the ILC considers their conduct analysed more appropriately under Article 7. ${ }^{130}$ This is the second means of attribution, where organs or agents are placed at the disposal of an international organization by a state. As in the case of states and paramilitary forces in the ICJ cases referred to in relation to state responsibility, the conduct of peacekeepers will not be attributable to the UN as an international organization unless it exercises effective control over them. Article 7 states,

The conduct of an organ of a State or an organ or agent of an international organization that is placed at the disposal of another international organization shall be considered under international law an act of the latter organization if the organization exercises effective control over that conduct.

While the UN's comments on the draft articles assume that it exercises effective control, this has not always been the case in practice. Military commanders have checked with their national governments before implementing orders of the UN Force Commander, as was the case, for example, in Somalia and Rwanda. ${ }^{131}$ Given the operating conditions of peacekeeping forces, the 'effective control' test may well be too stringent to ground accountability. The International Criminal Tribunal for Yugoslavia used a broader 'overall control' test in deciding on individual criminal responsibility in Tadic. ${ }^{132}$ By contrast, the ICJ in the Bosnian Genocide case reaffirmed the effective control test in deciding whether Serbia was liable under the international law on state responsibility for the acts of the Bosnian Serbs. ${ }^{133}$ Nigel White argues

The traditional test of effective control is inadequate for attribution to organizations such as the UN, NATO, or the EU, and to insist upon such

129 ILC 2011 art 2(d).

130 ibid commentary to art 7 [7]; C Leck, 'International Responsibility in United Nations Peacekeeping Operations: Command and Control Arrangements and the Attribution of Conduct' (2009) 10 Melbourne J Intl L 346, 350.

131 Hampson and Kihari-Hunt (n 54) 199; F Mégret, 'The Vicarious Responsibility of the United Nations' in C Aoi, E de Coning and R Thakur (eds), Unintended Consequences of Peacekeeping Operations (United Nations University Press 2007) 250, 260.

132 Prosecutor v Tadic (Appeals) (ICTY-94-1-A) (15 July 1999).

133 Application of the Convention on the Prevention and Punishment of the Crime of Genocide (Bosnia and Herzegovina v Serbia and Montenegro) (2007) ICJ Rep. 
a test would be to allow international organizations to escape direct liability for injurious acts committed under their authority. ${ }^{134}$

How much control states retain over their forces in peacekeeping operations was raised in the case of Behrami. Behrami concerned a boy who was killed by playing with an unexploded cluster bomb dropped on Kosovo by NATO. His brother, who was blinded in the incident, and father took action against France in the European Court of Human Rights. ${ }^{135}$ The Court considered whether French Kosovo Force (KFOR) (NATO) troops had failed to mark or defuse the undetonated bombs that troops knew to be present, but concluded that the UN was responsible. The Court held that KFOR (NATO)'s failure to secure the site and provide information to the UN Mission in Kosovo (UNMIK) did not alter UNMIK's mandate to de-mine. ${ }^{136}$ The Court analysed the issue of attribution on the basis that the UN mission in Kosovo was a subsidiary organ of the UN and its conduct was therefore attributable to the UN as a de jure organ of the UN. ${ }^{137}$ The Court found that the acts could not be attributed to a relevant state (ie, a party to the European Convention on Human Rights), as they did not take place on the territory of a state or by virtue of a decision of their authorities. Neither the UN nor NATO was party to the European Convention on Human Rights. The case was declared inadmissible because the relevant party, ie, the UN, was not before the Court.

The analysis in the Behrami decision has been much criticized. ${ }^{138}$ Most criticism is directed at the Court's analysis of control in the Articles on the Responsibility of International Organizations. ${ }^{139}$ In a report following the

134 ND White, 'Institutional Responsibility for Private Military and Security Companies' in F Francioni and N Ronzitti (eds), War by Contract: Human Rights, Humanitarian Law and Private Contractors (OUP 2011) 381, 383.

135 The application was joined with that of Saramati, a Kosovar who claimed that he had been unlawfully detained by KFOR troops: Agim Behrami \& Bekir Behrami v France; Ruzdhi Saramati v France, Germany \& Norway (2007) 45 ECtHR 41.

136 ibid [126].

137 ibid [143].

138 M Milanović and T Papić, ‘As Bad as it Gets: The European Court of Human Rights's Behrami and Saramati Decision and General International Law' (2009) 58 ICLQ 267; K Mujezinovic Larsen, 'Attribution of Conduct in Peace Operations: the "Ultimate Authority and Control" Test' (2008) 19 EJIL 509, 519, 523; A Breitegger, 'Sacrificing the Effectiveness of the European Convention on Human Rights on the Altar of the Effective Functioning of Peace Support Operations: a Critique of Behrami \& Saramati and Al Jedda' (2009) 11 Intl Community L Rev 155; H Kriegger, 'A Credibility Gap: the Behrami and Saramati Decision of the European Court of Human Rights' (2009) 13 J Intl Peacekeeping 159; A Sari, 'Jurisdiction and International Responsibility in Peace Support Operations: the Behrami and Saramati cases' (2008) 8 Human Rights L Rev 151; cf A Sari, 'Autonomy, attribution and accountability: Reflections on the Behrami Case' in R Collins and ND White (eds) International Organizations and the Idea of Autonomy: Institutional Independence in the International Legal Order (Routledge 2011) 257, 266-67.

139 P Bodeau-Livenec, GP Buzzini and S Villalpando, 'International Decision: Behrami \& Behrami v France; Saramati v France, Germany \& Norway' (2008) 102 AJIL 323, 327. 
decision, the Special Rapporteur on responsibility of international organizations notes that the Court used a different notion of control than the Special Rapporteur in his report to the ILC, and that the attribution of conduct should have been analysed as conduct of organs placed at the disposal of an international organization by a state.

Several commentators rightly observed that, had the Court applied the criterion of effective control set out by the Commission, it would have reached the different conclusion that the conduct of national contingents allocated to KFOR had to be attributed either to the sending state or to NATO. ${ }^{140}$

By focussing on control of territory, rather than control of the relevant activity, here mine clearing, the Court's analysis also ignores the fact that the ILC envisages the potential for dual or multiple attribution to states or international organizations. ${ }^{141}$ The Special Rapporteur criticized the Court's approach as 'unconvincing' and leading to the attribution to the UN of 'conduct which the organization has not specifically authorized and of which it may have little knowledge or no knowledge at all'. ${ }^{142}$ Although the analysis of international responsibility in Behrami was followed in a number of cases, ${ }^{143}$ the House of Lords distinguished it on the facts on the basis that the US and the UK forces in Iraq were not under the effective command and control of the UN. ${ }^{144}$ In deciding the appeal of Al-Jedda from the House of Lords, the European Court of Human Rights similarly distinguished Behrami on the facts, although it now admits 'the possibility of dual or multiple attribution of the same conduct to the UN and to a state'. ${ }^{145}$

The same issues regarding attribution of ultra vires conduct to states arise in respect of international organizations. The conduct of an organ or agent of the UN is imputable to the UN even if it exceeds the authority of that organ or agent or contravenes instructions, provided the organ or agent is acting in its official capacity. ${ }^{146}$ There are competing views as to whether off-duty conduct

${ }^{140}$ G Gaja, 'Seventh report of the Special Rapporteur on responsibility of international organizations' (27 March 2009) UN Doc A/CN.4/610 (Gaja's Seventh Report) [26].

141 ILC 2004 Commentary to Chapter II [4].

142 Gaja's Seventh Report [30]

143 Kasumaj v Greece App No 6974/05 (ECtHR 5 July 2007); Gajic v Germany App No 31446/02 (ECtHR 28 August 2007); Beric v Bosnia and Herzegovina: App No 36357/ 04 (ECtHR 16 October 2007) Case No 265615/HA ZA 06-1671, Judgment of 10 September 2008, District Court of the Hague, the Netherlands (finding that the behaviour of the Dutch contingent in the UN Protection Force in failing to prevent the massacre at Srebrenica should be attributed to the UN); Bodeau-Livenec and others (n 139) 330.

$144 R$ (on the application of Al Jedda) (FC) v Sec of State for Defence [2007] UKHL 58.

145 M Milanović, 'Al-Skeini and Al-Jedda in Strasbourg,' (forthcoming 2012) 23 EJIL; Al-Jedda v United Kingdom App No 27021/08, 7 July 2011.

146 ILC 2011 art 8. 
may be attributed to the UN. The UN argues it has 'no legal or financial liability for death, injury or damage resulting from such acts', and the ILC Commentary on this supports the view that an international organization, like a state, has no responsibility for 'the private actions or omissions of individuals who happen to be organs or agents' of an international organization. ${ }^{147}$ Nevertheless, it may be even more important to attribute wrongful conduct to the UN, because 'denying attribution of conduct may deprive third parties of all redress, unless conduct could be attributed to a State or another organization'. ${ }^{148}$ Frédéric Mégret argues that '[i]f peacekeepers routinely abuse local women sexually while taking breaks from the mission's work, then one would expect that it would fall upon the UN to correct that behaviour, especially if national commanding structures are indifferent or even complicit' ${ }^{149}$ The UN continues to accept responsibility for the acts of peacekeepers and the UN has recognized its obligation to compensate violations of IHL committed by peacekeepers. ${ }^{150}$ By analogy, an international organization such as the UN 'should be responsible for unlawful acts committed by contractors acting under its authority, command and control'. 151

Nevertheless, the most appropriate solution in this situation may well be attributing the conduct to both the UN and states. ${ }^{152}$ The ILC acknowledges the possibility of 'dual or even multiple attribution' of conduct. ${ }^{153}$ This provides states, which arguably have more control over their personnel, as well as the UN, with an incentive to prevent 'outrageous' conduct. ${ }^{154}$ Ironically, Behrami, which subordinated the regulatory objective of holding states responsible for breaches of international law to political concerns about future peace operations, could have the opposite of its intended effect by increasing the risk of

147 Ibid, Commentary to art 8 [4], [9]. Leck specifically refers to sexual exploitation and abuse and human trafficking as not incurring the responsibility of the UN 'given that these acts cannot be considered part of the official functions of the UN.' Leck (n 130) 351.

148 ILC 2004, Commentary to art 8 [6]. See also Sauri (n 128) 521-22.

149 Mégret (n 131) 258.

150 - , 'Financing of the UN Protection Force, the UN Confidence restoration operation in Croatia, the UN preventative deployment force and the UN Peace Forces Headquarters: Administrative and Budgetary Aspects of the Financing of the UN Peacekeeping Operations: Financing of the UN Peacekeeping Operations, Report of the Secretary-General' (20 September 1996) UN Doc A/51/389 [16].

151 White (n 134) 387.

152 Leck (n 130) 363.

153 ILC 2011, Commentary on ch II [4] 83.

154 cf the liability scheme proposed by Tom Dannenbaum, which attributes liability to the UN or to troop-contributing countries according to which category the act falls into: $\mathrm{T}$ Dannenbaum, 'Translating the Standard of Effective Control into a System of Effective Accountability: How Liability Should be Apportioned for Violations of Human Rights by Member State Troop Contingents Serving as United Nations Peacekeepers' (2010) 51 Harv Intl LJ 114, 158-83; P Rowe, 'UN Peacekeepers and Human Rights Violations: the Role of Military Discipline' (2010) 51 Harv Intl LJ Online 69. 
harm to local people. The UN had already abdicated disciplinary control over peacekeepers; Behrami, and the series of cases that adopted its reasoning, added momentum to this trend for the UN to hand over as much responsibility as possible for discipline and control to troop contributing countries. However, recent court decisions are more open to the possibility of dual attribution. In Nuhanović $v$ Netherlands, the Court of Appeal of The Hague found the Netherlands liable under Dutch law for the deaths of four Bosnian nationals who were evicted from the Dutch Battalion compound at Srebrenica in 1995. ${ }^{155}$ While holding the state of the Netherlands liable for a breach of Dutch tort law, it decided the issue of attribution on the basis of international law using the standard of 'effective control' as reflected in the ILC Draft Articles on the Responsibility of International Organizations. ${ }^{156}$ The court also acknowledged the possibility of dual attribution without making a finding on the UN's liability in the case. ${ }^{157}$ In another case in the Netherlands, the Mothers of Srebrenica sued the Netherlands and the UN for failing to prevent the genocide in $1995 .{ }^{158}$ A court of first instance still needs to consider the claim against the Netherlands, and the District Court declined to make a finding on the claim against the UN in light of its immunity. The plaintiffs are appealing the decision to the Dutch Supreme Court. ${ }^{159}$

Given that most peacekeeping operations are located in Africa and Asia, very few local people who suffer injury as a result are able to raise their claims in a human rights forum such as the European Court of Human Rights. ${ }^{160}$ This demonstrates the lack of effective enforcement mechanisms, regional or international, for the standards set by international law on state and international responsibility. In light of the complex array of actors that play important roles in peacekeeping operations, which increasingly involve NGOs and PMSCs in

155 Gerechtshof's Gravenhage (Court of Appeal) Hasan Nuhanovićv Netherlands Appeal Judgment LJN: BR5388, 5 July 2011, also published as Nuhanovic v Netherlands Appeal Judgment, LJN: R5388; ILDC 1742 (NL 2011), 5 July 2011; Gerechtshof's Gravenhage (Court of Appeal) Mustafić v Netherlands Appeal judgment, LJN: BR5386, 5 July 2011.

156 A Nollkaemper, 'Dual Attribution: Liability of the Netherlands for Conduct of Dutchbat in Srebrenica' Amsterdam Centre for International Law Research Paper no 2011-11 (SHARES Series) 5.

157 ibid 11.

158 Gerechtshof's Gravenhage (Court of Appeal) Mothers of Srebrenica v the Netherlands and the United Nations Appeal Judgment, LJN:BL8979, 30 March 2010.

159 Nollkaemper (n 156).

160 The decision of the European Court of Human Rights in Al-Skeini expands its jurisdiction in relation to the extraterritorial application of human rights treaties: Al-Skeini and others $v$ United Kingdom App No 55721/07, 7 July 2011. Courts include the Protocol to the African Charter on Human and People's Rights on the establishment of an African Court on Human and Peoples' Rights (adopted 10 June 1998, entered into force 25 January 2005) <http://www.achpr.org/english/_info/court_en.html> accessed 15 November 2011. The court has only given judgment in one case: $<$ http://www.claiminghumanrights.org/au_court.html? \&L=0> accessed 15 November 2011. There is no court of human rights for the Asia Pacific region. 
addition to numerous states and international organizations, dual or multiple attribution is an important regulatory strategy. This analysis of the law of attribution demonstrates that the standards it sets on control are unsettled and confusing, and the standards on multiple attribution contradict its regulatory objectives.

What, then, of the compliance monitoring and enforcement elements of the law on international responsibility? While the law of international responsibility provides for remedies in the form of reparations, the effectiveness of the remedies depends on the ability of claimants to enforce these rights. Crucially, the law envisages states and international organizations, rather than individuals, as making these claims. Individuals are forced to rely on states to make claims on their behalf at the international level. For example, the UN paid lump sums to the governments of non-Congolese nationals in settlement of claims relating to damage arising from its operations in the Congo 1960-64 'without prejudice to the privileges and immunities of the United Nations'. ${ }^{161}$ However, this method of payment is problematic because it assumes, first, that the state will make a claim on behalf of its affected nationals and, second, that the state will distribute the funds fairly to the nationals involved. ${ }^{162}$ In fact, this exercise of diplomatic protection is not obligatory but taken at the discretion of the state. ${ }^{163}$

Most complaints against the UN do not relate to combat but to where UN forces are assisting in police or humanitarian functions. ${ }^{164}$ The UN model SOFA envisages standing claims commissions with a panel of three members (one UN representative, one host state representative and a chair appointed by both) to determine private law claims, but these have never been established. This may have been due to a lack of interest by host states or satisfaction with existing procedures. ${ }^{165}$ The UN 'internal' claims review boards, composed exclusively of UN personnel, established in their stead may be perceived as too close to the UN personnel who are the subject of complaints. ${ }^{166}$ The local review boards must distinguish between combat-related activities, governed by IHL, and the ordinary operation of the force. The UN does not accept responsibility for 'off-duty acts of members of a UN peace operation', thereby distinguishing between 'conduct committed in a private capacity, on the one hand, and conduct committed in an official capacity, even if in excess of authority or in contravention of instructions, on the other hand'. ${ }^{167}$ Further, the General Assembly has

161 Exchange of Letters constituting an Agreement relating to the settlement of claims filed against the United Nations in the Congo by Belgian Nationals (Belgium-United Nations) (20 February 1965, entered into force 17 May 1965) UNTS 7780 cited in Clapham (n 123) 117.

162 Mégret (n 131) 264.

163 Zwanenberg (n 53) 42.

164 Clapham (n 123) 120.

165 -, 'Administrative and budgetary aspects of the financing of the United Nations peacekeeping operations: financing of the United Nations peacekeeping operations, Report of the Secretary-General' (21 May 1997) UN Doc A/51/903 [8].

166 Mégret (n 179) 263.

167 Zwanenberg (n 53) 31. 
placed temporal and financial limits on the extent of the UN's liability to third parties resulting from peacekeeping operations. ${ }^{168}$

A specific mechanism has been established by the UN to deal with complaints of sexual exploitation and sexual abuse. ${ }^{169}$ Compensation is particularly important in covering the medical costs of sexually transmitted diseases and providing financial support to children whose peacekeeper fathers have abandoned them. ${ }^{170}$ Medical, legal and psychosocial needs, as well as provision of food, shelter and clothing is envisaged to be provided through pre-existing services, such as NGOs, as monitored by a UN focal point. The major challenges in implementing the victim-assistance strategy are the absence of networks on protection from sexual exploitation and abuse and the lack of community-based reporting and complaints mechanisms. ${ }^{171}$ The UN has also identified facilitation of claims for financial support of peacekeepers' children as a priority as evidenced by amendments to the model MOU. Nevertheless, given that states retain discretion over whether they will join the relevant treaty regimes that oblige them to recognize foreign court orders in respect of maintenance payments, ${ }^{172}$ individual claimants remain in a legal limbo, unable to hold either the UN or states responsible. ${ }^{173}$ The problems of holding states, international organizations or individuals responsible are particularly evident in regard to the law of immunity.

\section{Immunity}

The regulatory purpose of immunity is to allow legal persons, such as states or international organizations, to function by shielding them, and in some cases their human agents, from the jurisdiction of a foreign state. Immunity has been conceptualized as 'a legal relationship which implie[s] a right for the State official not to be subjected to foreign criminal jurisdiction and a corresponding

168 Third-Party liability: temporal and financial limitations, GA Res 52/247 (17 July 1998) UN Doc A/RES/52/247 [8]-[11].

169 -, 'United Nations Comprehensive Strategy on Assistance and Support to Victims of Sexual Exploitation and Abuse by United Nations staff and related personnel' (Report, 7 March 2008) UN Doc A/RES/62/214.

170 Sweetser (n 74) 1662.

171 - , 'Implementation of the United Nations Comprehensive Strategy on Assistance and Support to Victims of Sexual Exploitation and Abuse by United Nations Staff and Related Personnel, Report of the Secretary-General' (27 July 2009) UN Doc A/64/176 [55].

172 Hague Convention on the Recognition and Enforcement of Decisions relating to Maintenance Obligations (adopted 2 October 1973, entered into force 1 August 1976) 1021 UNTS 209.

173 See for example, the case of Marko Susnja, whose Bosnian father was a UN peacekeeper deployed in East Timor: L Murdoch, 'Plea for boy left behind by UN dad' The Age (Melbourne, 2 May 2009), 1. 
obligation incumbent upon the foreign State concerned' ${ }^{174}$ Its rationale is found in the principles of 'sovereign equality of States and non-interference in internal affairs, as well as in the need to ensure the stability of international relations and the independent performance of State activities'. ${ }^{175}$ At international law, the primary model of immunity is sovereign or foreign state immunity, which exempts states from suit in foreign courts. ${ }^{176}$ The immunity of international organizations is based on a state immunity model. Like a corporation at domestic law, an international organization has a separate personality from those of its Member States at international law. ${ }^{177}$ The Charter of the United Nations grants immunity to the UN. ${ }^{178}$ A practical example of the regulatory function of immunity in the peacekeeping context is that immunity exempting the UN from suit in the courts of the host state prevents a peacekeeping mission from being undermined by constant legal action taken by its political opponents. ${ }^{179}$

While the UN is entitled to immunity from legal process under the UN Charter and the Convention on the Privileges and Immunities of the United Nations, it undermines the regulatory purpose of such immunity for it to be absolute. The European Court of Human Rights has held that the immunity of international organizations may be contingent on providing "'reasonable alternative means" by which to settle disputes and press claims' ${ }^{180}$ August Reinisch maintains that domestic courts should reject an international organization's claim of immunity where it fails to provide an adequate alternative internal remedy. ${ }^{181}$ In employment disputes, domestic courts increasingly perform a 'human rights impact assessment' in deciding whether immunity should be granted to international organizations. Catherine Sweetser argues that this duty is heightened in the case of human rights abuses. ${ }^{182}$ Organizations are

174 International Law Commission, Report on the Work of its Sixtieth Session UN Doc A/ 63/10 Supp No 10 (5 May-6 June and 7 July-8 August 2008) Chapter X, Immunity of State Officials from Foreign Criminal Jurisdiction [284].

175 ibid [274].

176 See further H Fox, The Law of State Immunity (OUP 2008); UN Convention on Jurisdictional Immunities of States and their property (adopted 2 December 2004, not yet in force) art 5: text available at $<\mathrm{http}$ ://untreaty.un.org/ilc/texts/instruments/ english/conventions/4_1_2004.pdf> accessed 3 December 2011.

177 International Law Commission, Report on the Work of its Sixty-first Session UN Doc A/64/10 (4 May-5 June and 6 July-7 August 2009) (ILC 2009) art 2(a); Reparations for injuries suffered in the service of the United Nations (Advisory Opinion) [1949] ICJ Rep 174, 179.

178 Charter of the United Nations (adopted 26 June 1945, entered into force 24 October 1945) (UN Charter) art 105.1.

179 Mégret (n 131) 255.

180 Waite v Germany App No 26083/94, 1999-I ECtHR 68 (1999) cited in Sweetser (n 73) 1675.

181 A Reinisch, International Organizations Before National Courts (CUP 2000) 313.

182 Sweetser (n 73) 1676. 
entitled only to functional immunity, so that when actions cannot be justified as part of the organization's functions, immunity should not be available. ${ }^{183}$

Officials of international organizations enjoy immunity by analogy with diplomatic immunity. ${ }^{184}$ Head of state and diplomatic immunity is usually conceptualized as flowing from state immunity, since states act through their human agents. ${ }^{185}$

In principle, an individual performing acts on behalf of a sovereign state may not be called to account for any violations of international law he may have committed while acting in an official function. Only the state may be held responsible at the international level. ${ }^{186}$

Immunity of state officials is often regarded as being either immunity rationae personae (personal immunity) or rationae materiae (functional immunity). ${ }^{187}$ Likewise, under the UN Charter, UN officials enjoy 'such privileges and immunities as are necessary for the independent exercise of their functions in connexion with the Organization'. ${ }^{188}$ The immunity from which individual officials benefit is functional, as the rationale for the grant of privileges and immunities is 'in the interests of the United Nations and not for the personal benefit of the individuals themselves'. ${ }^{189}$ To avoid the problem of impunity, the immunity of UN personnel may be waived by the Secretary-General where it would impede the course of justice and can be waived without prejudice to the interests of the United Nations'. ${ }^{190}$ The UN is obliged to cooperate with states to prevent the occurrence of any abuse of privileges and immunities. ${ }^{191}$

The immunity of UN officials provided for in the UN Charter is expanded in the Convention on Privileges and Immunities of the United Nations, which sets out three broad categories of personnel who enjoy different types of immunities. First, senior UN officials, such as the Secretary-General and the Special

183 ND White and S MacLeod, 'EU Operations and Private Military Contractors: Issues of Corporate and Institutional Responsibility' (2008) 19 EJIL 965, 986.

184 'The person of a diplomatic agent shall be inviolable. He shall not be liable to any form of arrest or detention. The receiving State shall treat him with due respect and shall take all appropriate steps to prevent any attack on his person, freedom or dignity': Vienna Convention on Diplomatic Relations (opened for signature 18 April 1961, entered into force 25 February 1968) 500 UNTS 95 art 29.

185 The ICJ notes that by claiming immunity from legal process for the acts of its officials, Djibouti thereby acknowledged state responsibility for those acts: Certain Questions of Mutual Assistance in Criminal Matters (Djibouti v France) (Merits) [2008] ICJ Rep 177 [196].

186 Cassese (n 44) 302.

187 International Law Commission (n 174).

188 UN Charter art 105.2.

189 Convention on the Privileges and Immunities of the United Nations (adopted 13 February 1946, entered into force 17 September 1947) 1 UNTS 15 (Convention on UN Privileges and Immunities) art VI s 23.

190 ibid art V s 20.

191 ibid art V s 21. 
Representatives of the Secretary-General (SRSG) who head peacekeeping missions, enjoy diplomatic immunity. ${ }^{192}$ In addition, the model UN SOFA grants diplomatic immunity to the Force Commander and Civilian Police Commander. ${ }^{193}$ Second, officials, who in peacekeeping operations comprise largely the civilian staff, attract functional immunity. This means that they are 'immune from legal process in respect of words spoken or written and all acts performed by them in their official capacity'. ${ }^{194}$ This appears to apply against the exercise of their sending state jurisdiction as well as against host state jurisdiction. ${ }^{195}$ The UN civilian staff members without the status of 'officials' are also protected by functional immunity from host state jurisdiction based on the SOFA, with UN Volunteers treated as 'officials' in recent SOFAs and other civilians regarded as experts on mission. ${ }^{196}$ Third, experts on mission attract the same functional immunity as the UN officials. Military Observers and the UN police are considered to be experts on mission. ${ }^{197}$ Their immunity continues after their employment on missions for the UN ceases. ${ }^{198}$ They also enjoy immunity from arrest or detention and from seizure of their personal baggage; inviolability for documents and UN communications; and privileges in relation to currency and personal baggage. The UN secretariat has drafted a Convention to cover the jurisdictional gaps that may enable UN officials and experts on mission to escape responsibility for serious crimes, but it has not been adopted by states. ${ }^{199}$

Immunity from criminal prosecution under host state law is granted to members of national contingents, who comprise the bulk of peacekeeping forces, under mission-specific treaties. There are two types of treaties that provide immunity to national contingent members in UN peacekeeping operations. The first is SOFAs between the host state and the UN, usually based on the UN model SOFA. ${ }^{200}$ The second is Agreements between sending states (troop-contributing countries) and the UN, usually based on the UN model

192 ibid art V s 19. While diplomatic immunity does not apply against the sending state, in the case of senior UN officials there is no sending state. The immunity of the SRSG may be waived by the Secretary-General and the immunity of the Secretary-General can be waived by the Security Council: art V s 20.

193 Model SOFA art 24: B Oswald and S Finnin, 'Combating the Trafficking of Persons on Peace Operations' in H Langholtz, B Kondoch and A Wells (eds), International Peacekeeping: The Yearbook of International Peace Operations, vol 10 (Martinus Nijhoff 2006) 1, 22.

194 They also benefit from other privileges and immunities in relation to taxation, national service, immigration, repatriation and customs as well as privileges and immunities enjoyed by diplomats: Convention on UN Privileges and Immunities art V, s 18(a).

195 Hampson and Kihari-Hunt (n 54) 203.

196 ibid 201.

197 Model SOFA art 26.

198 Convention on UN Privileges and Immunities art VI s 22(b).

199 Draft Convention on Criminal Accountability; 'Criminal accountability of United Nations officials and experts on mission' GA Res 64/110 (1 December 2010) UN Doc A/RES/64/110.

200 Model SOFA art 47(b). 
Memorandum of Understanding (MOU). ${ }^{201}$ Under these treaties, national contingent members are subject to the exclusive criminal jurisdiction of the sending state, which may be court martial or normal (ie civilian) criminal jurisdiction where it has extraterritorial application. ${ }^{202}$ Originally, this immunity was granted in exchange for assurances from troop-contributing countries that they would prosecute their troops in appropriate circumstances for any crimes committed on mission. ${ }^{203}$ This practice has fallen into disuse, although its revival has been recommended. ${ }^{204}$ Privileges and immunities are specified in the SOFA but there may not always be a SOFA. Sometimes peace operations may deploy before a SOFA has been negotiated or there is no government with whom to negotiate one. ${ }^{205}$ Even without a SOFA in force, members of national contingents may be protected by sovereign immunity. ${ }^{206}$ In these circumstances, it is likely that the provisions of the UN model SOFA would be referred to, although there is no SOFA in force. This possibility demonstrates the legal uncertainty surrounding the status of UN peacekeepers and the criminal jurisdiction that should apply to them. Nevertheless, the functional basis of immunity implies that those benefitting from immunity must comply with local law and that a mechanism for determining waiver of immunity should be available..$^{207}$

Although private military contractors do not fall into the category of persons who would normally enjoy immunity at international law, in some cases they have acquired it under treaties or executive orders. ${ }^{208}$ In the peacekeeping context, the Dayton Accords on Bosnia grant immunity to the International Police Task Force (IPTF). ${ }^{209}$ This immunity also applied to the private military contractors who comprised the bulk of the US contribution to the IPTF. However, immunity is not available for grave breaches of the Geneva Conventions in an international conflict. ${ }^{210}$

201 Manual on Policies and Procedures concerning the Reimbursement and Control of Contingent-owned Equipment of Troop/Police Contributors participating in Peacekeeping Missions (COE Manual) UN Doc A/C.5/63/18 (2009) ch 9.

202 Hampson and Kihari-Hunt (n 54) 203.

203 Model SOFA art 48; DW Bowett, United Nations Forces (Frederick A Praeger 1964) 512.

204 The Zeid Report [78].

205 Hampson and Kihari-Hunt (n 54) 202.

206 ibid 199.

207 Bowett (n 203) 432.

208 For example, Coalition Provisional Authority Order no 17 granted contractors immunity from Iraqi law in 2003. The immunity was lifted on 1 January 2009, enabling security contractors to be prosecuted under Iraqi law. Coalition Provisional Authority Order No 17 (Revised) Status of the Coalition Provisional Authority, MNF-Iraq, Certain Missions and Personnel in Iraq <http://www.iraqcoalition.org/regulations/ 20040627_CPAORD_17_Status_of_Coalition_Rev_with_Annex_A.pdf $>$ accessed 6 May 2010, s 4(3).

209 General Framework Agreement for Peace in Bosnia and Herzegovina 35 ILM 751996 (signed and entered into force 14 December 1995), Annex 1A, Annex 11.

210 Lehnardt (n 58) 1031. 
The privileges and immunities of UN officials and experts on mission can lead to lack of accountability in practice, as, unlike in the case of diplomats, UN civil servants are potentially immune including from their sending state's jurisdiction. ${ }^{211}$ As a way of counteracting this potential problem, the UN has an obligation to establish dispute settlement mechanisms for contracts or other private law disputes to which the UN is a party. ${ }^{212}$ The potential for lack of accountability is a particular problem in situations where the UN is both leading a peacekeeping mission and effectively acting as an administration, such as in East Timor, Kosovo and Cambodia, but has proven problematic elsewhere as well. It is official UN policy that

officials and experts on mission should be held accountable whenever they commit criminal acts, particularly crimes related to sexual exploitation and abuse, human trafficking, fraud and corruption, not only because of the prejudice or harm caused to the victims, but also because they undermine the work and image of the United Nations. ${ }^{213}$

Since 2000, there has been a change in the UN's longstanding practice of interpreting privileges broadly to protect the organization. In 2000, two Jordanian Civilian Police were tried by East Timorese courts for the alleged rape of an East Timorese woman following the determination of the Special Representative of the Secretary-General that rape could not be construed as 'official' or 'necessary' and hence the issue of waiver from the Secretary-General did not arise. In Kosovo, a UN staff member accused of involvement in genocide in Rwanda was denied immunity, as were police accused of rape and murder. ${ }^{214}$ However, there is confusion about when an act is not part of official duties and therefore does not attract immunity, and when an act would normally attract immunity but in the particular case a decision has been taken to waive that immunity. The immunity of a Jordanian Civilian Police officer accused of rape in East Timor was initially waived, then later immunity was held to be inapplicable to rape. ${ }^{215}$ The immunity of a UN staff member accused of murder in Kosovo was waived, whereas a better analysis is that the act was outside the scope of the immunity, as it could not have been part of official duties. ${ }^{216}$ There may also be human rights considerations for upholding immunity, as to deny or waive immunity might raise concerns about permitting a staff member to be

211 Hampson and Kihari-Hunt (n 54) 199-200.

212 Convention on UN Privileges and Immunities art VIII s 29. The claims commissions envisaged in the UN Model SOFA art 51 are an example of this: Mégret (n 131) 256.

213 -, 'Information-sharing practices between the United Nations and national law enforcement authorities, as well as referrals of possible criminal cases related to United Nations staff, United Nations officials and experts on mission Report of the Secretary General' (25 August 2008) UN Doc No A/63/331[12].

214 Rawski (n 61) 119-20.

215 Hampson and Kihari-Hunt (n 54) 207.

216 ibid 202. 
subject to local criminal process, or concerns that the death penalty might be imposed. ${ }^{217}$ Overall, monitoring and enforcement of the standards set by the law of immunities remains weak.

The ICJ can review decisions of the UN Secretary-General on immunity and waiver. ${ }^{218}$ The ICJ has provided advisory opinions in two cases concerning the immunities of UN experts on mission, Cumaraswamy ${ }^{219}$ and Mazilu. ${ }^{220}$ Dato' Param Cumaraswamy, Special Rapporteur of the Commission on Human Rights on the independence of judges and lawyers, was sued for defamation as a result of an interview he gave to a magazine in his home state of Malaysia. Dumitru Mazilu, Special Rapporteur of the Sub-Commission on Prevention of Discrimination and Protection of Minorities, was prevented by his government, Romania, from completing his report and attending consultations in Geneva. In both cases, the ICJ upheld the immunity of the experts on mission as it regarded them as being subjected to harassment by their sending states, Malaysia and Romania, respectively, due to the experts' performance of their official duties. While not directly relevant to the issue of UN officials' immunity, the ICJ has also upheld the immunity of the Foreign Minister of the DRC from an arrest warrant issued by Belgium for his involvement in serious violations of IHL. The ICJ did not distinguish between acts performed in an 'official' capacity and a 'personal' capacity, or between acts committed while he was Foreign Minister and those committed before he assumed office. ${ }^{221}$ The Court found some exceptions that might permit prosecution, including the prosecution of persons accused of war crimes or crimes against humanity where the state which they represent decides to waive immunity, where they are tried in their own state, where they no longer enjoy immunity after ceasing to hold office or where an international criminal court has jurisdiction. ${ }^{222}$ Nevertheless, the ICJ upheld immunity in all three cases that came before it. ${ }^{223}$

Immunity from jurisdiction is often invoked or assumed to apply to sexual crimes committed by peacekeepers, although it is rarely argued that having sex is in the course of official duties for a peacekeeper. ${ }^{224}$ It has been pointed out that 'acts of sexual exploitation and abuse will never be acts performed in the

217 AJ Miller, 'Legal Aspects of Stopping Sexual Exploitation and Abuse in U.N. Peacekeeping Operations' (2006) 39 Cornell Intl LJ 71, 92.

218 Convention on UN Privileges and Immunities art VIII s 30.

219 Difference relating to Immunity from Legal Process of a Special Rapporteur of the Commission on Human Rights (Advisory Opinion), [1999] ICJ Rep 62.

220 Applicability of Article VI, Section 22, of the Convention on the Privileges and Immunities of the United Nations (Advisory Opinion) [1989] ICJ Rep 177.

221 Democratic Republic of the Congo v Belgium (Arrest Warrant) (Merits) [2002] ICJ Rep 3.

222 ibid 213.

${ }^{223}$ Cf $R v$ Bow Street Stipendiary Magistrate and others, ex parte Pinochet Ugarte [1999] UKHL 17, 2 All ER 97.

${ }^{224}$ For an argument that sex is in the course of official duties of peacekeepers in the context of a discussion on the responsibility of the UN as an international organization, see Mégret (n 131) 258. 
course of official functions'. ${ }^{225}$ However, if rape were committed pursuant to orders from commanders, as was the case in the former Yugoslavia and in Rwanda, it might constitute a war crime, ${ }^{226}$ a crime against humanity ${ }^{227}$ or genocide, ${ }^{228}$ depending on whether the other elements of these crimes were met (such as a nexus to armed conflict for war crimes; constituting a widespread or systematic attack on the civilian population for crimes against humanity). Were an individual to be prosecuted for such international crimes, or for torture or grave breaches of the Geneva Conventions, immunity would not apply. ${ }^{229}$

To what extent does the international law on immunity meet the definition of a regulatory regime? In terms of a standard-setting function, it provides that the immunity of senior UN officials, such as the Special Representative of the Secretary-General, the peacekeeping Force Commander and the Police Commander, is absolute. The immunities of experts on mission only apply where they are 'necessary for the independent exercise of their functions', ${ }^{230}$ likewise, UN officials only benefit from immunity for conduct 'performed by them in their official capacity'. ${ }^{231}$ Immunity can be waived where 'it would impede the course of justice and can be waived without prejudice to the interests of the United Nations'. ${ }^{232}$ Hence, there are reasonably clear standards on when immunities apply and when they can be waived. However, some of the standards are problematic in themselves. For example, there may be instances in which it would be appropriate to waive the immunity of the Special Representative of the Secretary-General, the Force Commander or the Police Commander, but that is not possible as immunity is absolute. In relation to functional immunity of officials and experts on mission, waiver is possible where immunity is not in the interests of the UN. However, the UN may have conflicting interests, such as political pressure to retain credibility and the need to hold peacekeepers accountable for crimes they have committed, and it is for the UN SecretaryGeneral, rather than an external body such as the ICJ, to decide what is in the UN's interests.

Moreover, there are serious deficiencies with the monitoring of compliance with and enforcement of these standards. In relation to the immunities of UN officials and experts on mission, the UN Secretary-General's decisions relating to waiver are subject to ICJ review. However, the rules about who may request an advisory opinion from the ICJ are strict; only certain UN entities may request an opinion, leaving those most affected, such as victims of crime,

Miller (n 217) 92.

226 Prosecutor v Furundžija (Judgment) ICTY-95-17/1, 10 December 1998.

227 Prosecutor v Kunarac (Appeal) ICTY-96-23 \& ICTY-96-23/1,12 June 2002.

228 Prosecutor v Akayesu (Judgment) ICTR-96-4, 2 September 1996, [688], [731]-[3].

229 Cassese (n 44) 305. See also the Rome Statute art 27.

${ }^{230}$ Convention on UN Privileges and Immunities art VI s 22.

231 ibid art V s 18(a).

232 ibid art V s 20. 
disenfranchised. ${ }^{233}$ Although sending states have a duty to ensure compliance with local law under SOFAs, their decisions about waivers of immunity enabling host state prosecution of national contingent members are not subject to any international legal scrutiny. A more flexible policy on waivers of immunity, particularly where claimants would have no other access to a remedy, would further the regulatory objectives of immunity. ${ }^{234}$ Hence, while international law provides some guidance on standards and situations in which immunity should be waived, its provision for monitoring of compliance and enforcement of these standards is weak.

In terms of Teubner's regulatory trilemma, the law of immunity can also be said to be incoherent, in that the social norms of impunity for sexual crimes committed by peacekeepers overwhelm the law of immunity. If the law were applied in accordance with its regulatory purpose, that is, to enable international organizations to function through their human agents, immunity would not be available. Hence, while there are problems with the standard set with regard to the interests of the UN, the major problems are the interpretation of the immunity contrary to its regulatory purpose and the lack of effective monitoring of compliance with and enforcement of the standard.

\section{Conclusion}

This article has examined the question of how law regulates sexual crimes committed by peacekeepers. It approached the discussion of jurisdiction, the responsibility of states and international organizations, and immunity from a regulatory, rather than a doctrinal, perspective. Using the definition of a regulatory regime as one that sets standards, monitors compliance and enforces standards, it found that the strength of international law in these areas is in standard setting, but that there are still inadequacies in this area. International law is weak in both monitoring compliance and enforcement mechanisms. This is primarily because international law relies on states to undertake these functions, but states are often unwilling or unable to do so where sexual crimes committed by peacekeepers are concerned. Even where individuals have attempted to take enforcement action, for example, at the European Court of Human Rights, problems with the standards set by international law result in outcomes that undermine its regulatory objectives.

In order to improve the regulatory power of international law, we should recall the regulatory objectives of the particular topics discussed here. The rules on state jurisdiction are designed to provide guidance on which states

233 The General Assembly, the Security Council, and other organs of the United Nations and specialized agencies authorized to do so by the General Assembly may request an advisory opinion from the ICJ: UN Charter art 96.

234 Zwanenberg (n 53) 47. 
have competence over particular issues. A situation where no state has jurisdiction, such as where host state jurisdiction is prevented by the terms of a peacekeeping SOFA but a sending state fails to exercise jurisdiction as per the SOFA, potentially results in de facto impunity for members of national contingents. The controversy over the extent of control required to ground international responsibility undermines the standard-setting function of international law. The regulatory purpose of the law of immunity is to protect an individual who is carrying out official duties so that the only liability that flows from that action is in responsibility of states or international organizations. Achieving that regulatory purpose would mean an end to impunity for actions that are not within the course of official duties. The dependence of individuals on states to raise their claims for a remedy at international law is a weakness of both the compliance monitoring and enforcement aspects of the law of state and international responsibility as a regulatory regime.

As with the regulation of human rights abuses, the international legal regulation of sexual crimes committed by peacekeepers could be understood as 'a regulatory model of state accountability with weak enforcement' increasingly supplemented by 'a new regulatory model of individual legal criminal accountability'. ${ }^{235}$ However, a fundamental problem with the regulation of sexual crimes committed by peacekeepers is that there has been a breakdown in the operation of the international law of immunity, which undercuts individual accountability, and state or international responsibility. Logically, an individual who acts in an official capacity should be immune to individual liability but her conduct should be imputed to the state (or international organization). If the individual is not acting in an official capacity, she should be held responsible, not the state or international organization. However, in the case of sexual crimes committed by peacekeepers, immunities are held to apply even where acts are not official, but states are yet to take responsibility for them. International law also illustrates the risks of regulation. Based on Teubner's regulatory trilemma, international law can be shown to be irrelevant (in the case of jurisdiction) and incoherent (in the case of immunity and international responsibility). Overcoming these risks through recalling the regulatory objectives of international law could assist in creating a more effective international legal system.

235 K Sikkink, 'From State Responsibility to Individual Criminal Accountability: a New Regulatory Model for Core Human Rights Violations' in W Mattli and N Woods (eds), The Politics of Global Regulation (Princeton University Press 2009) 121, 121-22. 